\title{
IMPROVING NATIONAL-SCALE INVASION MAPS: TAMARISK IN THE WESTERN UNITED STATES
}

\author{
Catherine S. Jarnevich ${ }^{1,3}$, Paul Evangelista ${ }^{2}$, Thomas J. Stohlgren ${ }^{1}$, and Jeffery Morisette ${ }^{1}$
}

\begin{abstract}
New invasions, better field data, and novel spatial-modeling techniques often drive the need to revisit previous maps and models of invasive species. Such is the case with the at least 10 species of Tamarix, which are invading riparian systems in the western United States and expanding their range throughout North America. In 2006, we developed a National Tamarisk Map by using a compilation of presence and absence locations with remotely sensed data and statistical modeling techniques. Since the publication of that work, our database of Tamarix distributions has grown significantly.

Using the updated database of species occurrence, new predictor variables, and the maximum entropy (Maxent) model, we have revised our potential Tamarix distribution map for the western United States. Distance-to-water was the strongest predictor in the model $(58.1 \%)$, while mean temperature of the warmest quarter was the second best predictor $(18.4 \%)$. Model validation, averaged from 25 model iterations, indicated that our analysis had strong predictive performance (AUC $=0.93$ ) and that the extent of Tamarix distributions is much greater than previously thought. The southwestern United States had the greatest suitable habitat, and this result differed from the 2006 model. Our work highlights the utility of iterative modeling for invasive species habitat modeling as new information becomes available.
\end{abstract}

Resumen.-A menudo las nuevas invasiones, mejores datos de campo y técnicas novedosas de modelado espacial impulsan la actualización de los mapas y de los modelos existentes de especies invasoras. Este es el caso de al menos 10 especies de Tamarix, las cuales están invadiendo los sistemas ribereños en el oeste de los EE.UU. y extendiendo su distribución por toda Norteamérica. En 2006, desarrollamos un mapa nacional del tamarisco (National Tamarisk Map) utilizando una compilación de sitios de presencia y ausencia con datos de sensores remotos y técnicas de modelación estadística. Desde la publicación de este trabajo, nuestra base de datos sobre la distribución de Tamarix ha crecido considerablemente.

Utilizando la base de datos actualizada de presencia de especies, nuevas variables predictoras y el modelo de máxima entropía (Maxent), hemos modificado nuestro mapa de la distribución potencial de Tamarix para el oeste de los EE.UU. El predictor más fuerte en el modelo fue la distancia al agua (58.1\%), y la temperatura promedio del trimestre más cálido fue el segundo (18.4\%). La validación de modelo, calculada como el promedio de 25 iteraciones del modelo, indicó que nuestro análisis tuvo una alta capacidad predictiva $(\mathrm{ABC}=0.93)$, y que la distribución de Tamarix es mucho más extensa de lo que se pensaba. El suroeste de los EE.UU. tuvo la mayor cantidad de hábitat adecuado para la especie, y este resultado difirió del modelo de 2006. Nuestro trabajo enfatiza la utilidad del modelado iterativo para modelar el hábitat de las especies invasoras a medida que se disponga de nueva información.

Riparian ecosystems throughout the southwestern United States have been invaded by Tamarix species, collectively known as tamarisk or saltcedar. Introduced from Eurasia in the early 1800 s to control erosion, create windbreaks, and act as ornamentals, tamarisk was acclaimed for its ability to withstand drought, heat, and diverse soil conditions (Carleton 1914, DiTomaso 1998). However, by the mid-1900s, resource managers had witnessed tamarisk's remarkable ability to spread and modify ecosystem processes. As a result, the species have had dramatic, and often negative, effects on native flora, wildlife habitat, and hydrologic processes (Christensen 1962, Robinson 1965, Harris 1966). It was estimated that tamarisk occupied approximately 4000 ha in the 1920 s and had grown to more than 500,000 ha by the mid-1960s (Robinson 1965). Initially, tamarisk infestation was primarily confined to regions of the southwestern United States (i.e., Colorado, Arizona, New Mexico, Utah, and Texas) but now occurs throughout the northern and northwestern Great Plains (Lesica and Miles 2001, Sexton et al. 2006, Kerns et al. 2009) and, to a lesser extent, in several eastern states (Baum 1967, Pearce and Smith 2007, USDA NRCS 2009). Although tamarisk may be spreading at

\footnotetext{
${ }^{1}$ Fort Collins Science Center, U.S. Geological Survey, 2150 Centre Ave Building C, Fort Collins, CO 80526-8116.

${ }^{2}$ Natural Resource Ecology Laboratory, Colorado State University, Fort Collins, CO 80523-1499,
}

32E-mail: jarnevichc@usgs.gov 
a slower rate than in recent decades, there is no evidence that the invasion has reached its potential extent. Outside of the United States, tamarisk can now be found in Mexico (Scott et al. 2009), Canada (Lindgren et al. 2010), and South America (Natale et al. 2008), well beyond the latitudinal limits of its native range (Gaskin and Schaal 2002, Gaskin and Shafroth 2005). Anthropogenic influences on natural hydrological processes (Everitt 1980, 1998), and the species' ability to hybridize and adapt to new environments (Whitcraft et al. 2007) are concerning to resource managers; further invasions are likely to continue.

There are a number of statistical and geospatial models that have been developed recently to predict species habitat and potential distributions (Elith et al. 2006). These models are increasingly used by landscape ecologists and resource managers to map distributions and forecast new invasions of nonnative species (Elith et al. 2006, Evangelista et al. 2008). Most models rely on known occurrence locations (i.e., presence points) to identify ecosystem characteristics that define the species' habitat parameters and predict potential distribution across a landscape (Stockwell and Peters 1999, Phillips et al. 2006). Predictive models are of particular importance to resource managers because they identify the potential extent of infestations and highlight habitats that may be vulnerable to new invasion (National Invasive Species Council 2008). Model results can also offer insight into ecosystem characteristics that are either conducive or prohibitive for a particular species, while providing critical information on how an invader may respond to new habitats (Evangelista et al. 2008).

In 2006, Morisette et al. reported the first detailed national-scale model of suitable habitat for tamarisk in the United States. Since then, a significant number of new tamarisk infestations have been reported: some occurred in regions that had not previously been infested (Kerns et al. 2009), while others were simply absent from the original data set. New predictor variables have also become available in geospatial formats at national scales, including an expanded suite of climate data that may also lead to improvements in model performance. In addition, new modeling techniques, such as maximum entropy modeling (Maxent), are better suited for predicting tamarisk distributions with the types of data that are accessible
(Evangelista et al. 2008). Maxent is a newer technique applied to species distribution modeling that is especially suited for invading species because it compares presence locations to the available environment rather than trying to distinguish between presence and absence locations. Absence locations can be problematic when modeling invasive species because of the dynamic state of invading species' distributions (e.g., lag times).

Specifically, many new modeling techniques are designed to be fit with presence-only data and provide built-in features that evaluate model performance and predictive contributions of the tested variables. Morisette et al. (2006) used logistic regression, which requires presence and absence data for model development. Although a proven statistical technique in ecological modeling, logistic regression may not accurately represent absence data when the regression is used for invasive species. Obtaining true "absence" data at a scale commonly used for national-level models (e.g., $1 \mathrm{~km}^{2}$ ) is not simple for any species, much less for an invasive species that is continuing to expand its range. Models that can be fit with presence-only data are not constrained by assumed absences and thus may be better suited for predicting invasive species where the species may not occupy all suitable habitat (Hirzel et al. 2001, Brotons et al. 2004, Kumar et al. 2009).

In this paper, we revisit our National Tamarisk Map (Morisette et al. 2006) using revised data sets, new predictor variables, and a new modeling technique. Our objectives were to (1) improve our predictions of habitat suitability in light of new information for tamarisk at a national scale and (2) compare the methods and results of the 2 modeling approaches.

\section{Methods}

\section{Data Acquisition}

The tamarisk database used in this analysis was founded on the same occurrence information used in the National Tamarisk Map (Morisette et al. 2006), but it included additional data and data from a wider geographic extent (Fig. 1). Following the publication of Morisette et al. (2006), our team was contacted by a number of resource managers informing us of new infestations and large-scale gaps in the data used (e.g., North Dakota, South Dakota). Many of these contacts provided us with 


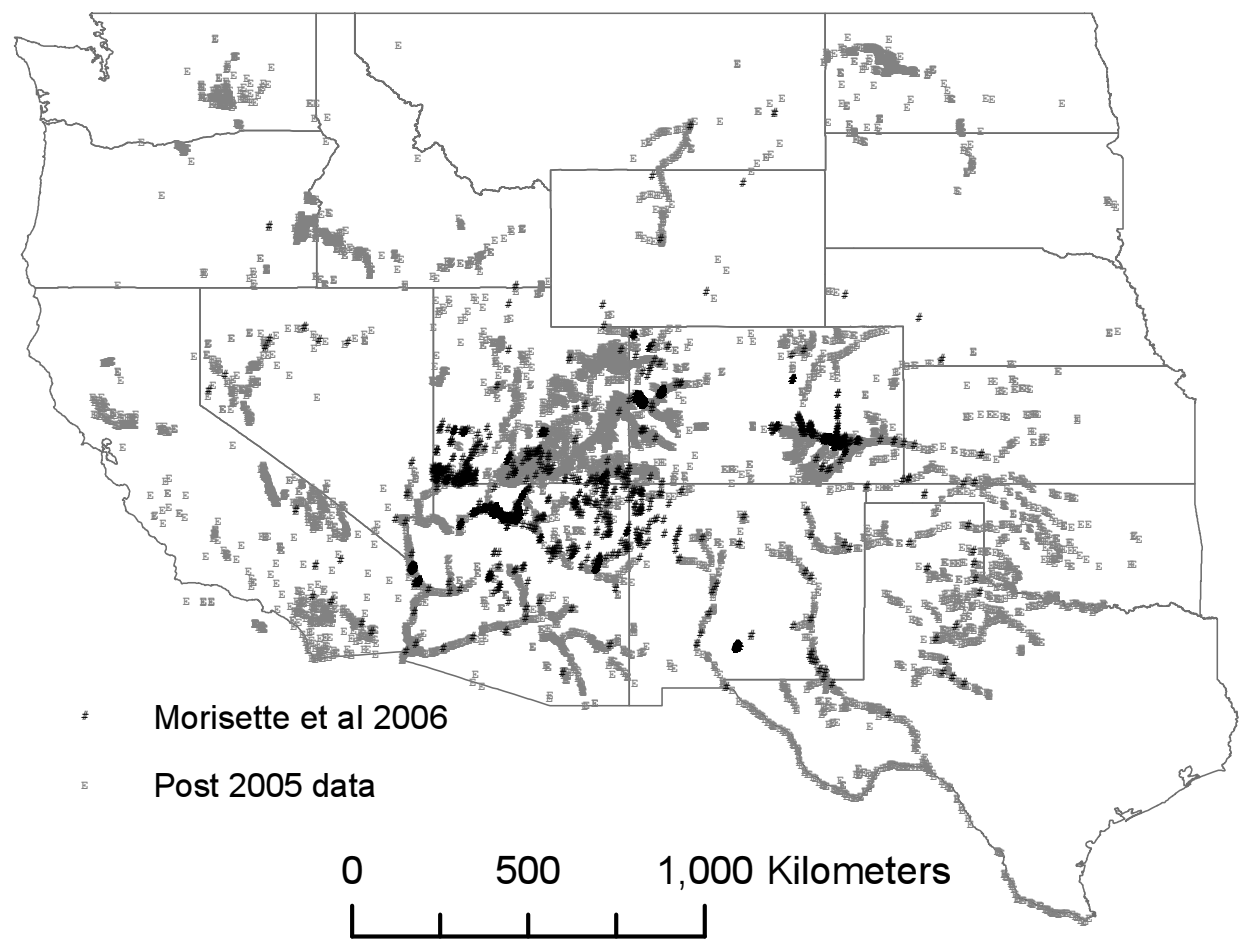

Fig 1. Point locations used in developing the habitat suitability model, with data used in the Morisette et al. (2006) tamarisk habitat suitability map in black and new data in gray. Projection: USA Albers Equal Area Conic.

new occurrence information to update our database. We also incorporated new tamarisk data that were reported to the National Institute of Invasive Species Science (NIISS) websites (i.e., http://www.tamariskmap.org and http:// www.niiss.org; Graham et al. 2007). We further supplemented our data set by contacting state weed coordinators and other researchers monitoring tamarisk distributions (e.g., http://www .TamariskCoalition.org) and through literature searches where actual occurrence coordinates were reported or where GIS layers were made available. These data included presence locations for tamarisk, but other information, such as abundance, was generally unavailable.

The GIS data we collected included point, line, and polygon formats. The point data did not require any manipulation beyond modifying geographic projection; however, the line and polygon data required processing to generate $x$ and $y$ coordinates. Line data were converted to $1-\mathrm{km}^{2}$ grids comparable to our predictor layers. To extract presence points for our analysis, we randomly selected $10 \%$ of the grid cells that represented linear tamarisk fea- tures. By selecting only $10 \%$ of the grid cells, we were able to capture the presence of the species in the related location but not artificially increase the sample size or create a highly clustered group of presence points. Polygon data had a relatively small scale, compared to the spatial resolution of predictor layers. Presence points were generated by calculating the centroid of each polygon feature and adding the coordinates to our tamarisk database. In total, we compiled 25 disparate data sets (including those from 2006; Appendix), which contained 25,563 records of tamarisk occurrence. All occurrence data were converted to a GIS raster format with a pixel size of $1 \mathrm{~km}^{2}$. When more than one presence point fell within a single pixel, that pixel represented a single occurrence for the purposes of our analysis. This process reduced our data set to 11,601 occurrence points.

We assembled 29 climatic, topographic, and geographic layers to use as predictors in the model (Table 1). Climatic data consisted of 19 bioclimatic variables describing the annual and seasonal variation in temperature and 
TABLE 1. Predictor variables used in the model and their relative contributions to the model.

\begin{tabular}{|c|c|c|}
\hline Predictor variable & Average $\%$ contribution (range) & Source \\
\hline Distance to water & $44.2(42.5-45.4)$ & $\begin{array}{l}\text { Derived from National Atlas } \\
\text { Rivers and Streams }\end{array}$ \\
\hline Mean temperature of the warmest quarter & $21.4(20.1-22.7)$ & Derived from DAYMET \\
\hline Precipitation of the wettest month & $7.3(5.1-9.2)$ & Derived from DAYMET \\
\hline Size of precipitation event & $4.1(3.1-5.4)$ & DAYMET \\
\hline Geology & $3.6(3.1-4.1)$ & $\begin{array}{l}\text { USGS product (http://pubs } \\
\text {.usgs.gov/dds/dds11/) }\end{array}$ \\
\hline Temperature seasonality & $3.4(2.7-3.9)$ & Derived from DAYMET \\
\hline Precipitation of the warmest quarter & $3.0(1.5-3.6)$ & Derived from DAYMET \\
\hline Mean temperature of the wettest quarter & $2.7(2.3-3.4)$ & Derived from DAYMET \\
\hline Precipitation seasonality & $2.1(1.5-3.0)$ & Derived from DAYMET \\
\hline Temperature annual range & $2.1(1.7-2.7)$ & Derived from DAYMET \\
\hline Elevation & $1.3(0.99-1.5)$ & $\begin{array}{l}\text { National Elevation Dataset } \\
\text { (http://ned.usgs.gov/) }\end{array}$ \\
\hline Radiation & $1.2(0.8-1.5)$ & DAYMET \\
\hline Humidity & $0.78(0.5-1.0)$ & DAYMET \\
\hline Precipitation of the coldest quarter & $0.7(0.5-1.1)$ & Derived from DAYMET \\
\hline Range in EVI & $0.4(0.2-1.0)$ & Derived from MODIS \\
\hline Precipitation of the driest month & $0.4(0.2-1.3)$ & Derived from DAYMET \\
\hline Isothermality & $0.3(0.2-0.5)$ & Derived from DAYMET \\
\hline Mean temperature of the coldest quarter & $0.3(0.1-0.5)$ & Derived from DAYMET \\
\hline Frequency of precipitation events & $0.3(0.1-0.5)$ & DAYMET \\
\hline Mean temperature of the driest quarter & $0.2(0.1-0.5)$ & Derived from DAYMET \\
\hline Slope (degrees) & $0.2(0.1-0.4)$ & $\begin{array}{l}\text { National Elevation Dataset } \\
\text { (http://ned.usgs.gov/) }\end{array}$ \\
\hline Mean of EVI & $0.1(0.1-0.4)$ & Derived from MODIS \\
\hline Mean diurnal range & $0.1(0.1-0.2)$ & Derived from DAYMET \\
\hline
\end{tabular}

precipitation (Hijmans 2006), including 8 DAYMET variables (i.e., number of frost and growing degree days, humidity, radiation, minimum and maximum temperature, and precipitation size, frequency, and annual average; Thornton et al. 1997). Topographic data included elevation, slope, and aspect. We also used a 3year mean and range of the Enhanced Vegetation Index (EVI) that was derived from the Moderate Resolution Spectroradiometer (MODIS), geology (primarily parent material), and Euclidean distance-to-water generated using toolsets available in ArcGIS software (ESRI 2006). We examined all variables for cross-correlations in Systat 12 software (SYSTAT software, San Jose, CA), and removed any highly correlated variables $(r>+0.8$ or $r<-0.8)$, leaving 23 predictor variables for our model. Although the modeling technique we describe below is not sensitive to issues of multicollinearity related to variable correlations, inclusion of highly correlated variables can affect variable contribution and interpretation of results. We were interested in examining these effects.
To validate the model, we compiled 2 different data sets. We gathered the absence data used in the 2006 paper as one validation data set and obtained an independent data set estimating acreage of tamarisk by quarter quadrangle (one quarter of a 7.5-minute USGS quadrangle) in the western United States. These data were compiled by the Western Weed Coordinating Committee; county weed coordinators reported an estimated acreage for each quarter quadrangle in their jurisdiction for 16 western states (i.e., our study area without Texas). While these data are based on expert knowledge (rather than actual field data) and are likely to have data gaps, the information is of value for testing needs.

\section{Spatial Modeling and Statistical Analysis}

For our analysis, we used the Maxent model version 3.2.1 (http://www.cs.princeton.edu/ 〜 schapire/maxent) (Phillips et al. 2006), which is increasingly being used for predicting species distributions and has performed well based on evaluation metrics such as those we describe below when applied to predicting and 
mapping tamarisk (Evangelista et al. 2008, 2009). Using the principle of maximum entropy, the Maxent model identifies relationships between species occurrence and the predictor variables in order to develop a habitat suitability map. Maxent requires presence-only data and extracts random background points from the training extent of the model (Phillips et al. 2006). Because Maxent is sensitive to sampling bias, background point selection was limited to counties for which we had samples, and the resulting model was projected to the entire western United States.

We conducted 25 separate model iterations, withholding 3480 presence points (30\% of our presence points) randomly selected prior to each analysis. Our analysis produced 3 maps: a habitat suitability map for the western United States that averaged the 25 model iterations, a map of standard deviation between the 25 iterations, and an average clamping map across the 25 iterations. The clamping map highlights locations in the model projection (the entire western U.S.) that have environmental conditions outside the range found within the training region (counties with data points), so predictions at these locations may have higher uncertainty associated with them.

Our model results were validated using several different statistical tests. First, Maxent calculates the area under the receiver operating characteristic curve (AUC), which is a measure of how well the model discriminates between presence locations and background locations (Fielding and Bell 1997). Maxent also calculates the 10 percentile training presence threshold that can be used to develop a binary map of suitable and unsuitable habitat. Additionally, we calculated the AUC, the correct classification rate, sensitivity, specificity, and kappa (Fielding and Bell 1997) using R statistical software (v 2.8.1; http://cran.r-project.org). These tests were conducted using the absence data from Morisette et al. (2006) and the quarter quadrangle data set. For each quarter quadrangle, we took the maximum suitability value from any pixel within the quarter quadrangle to calculate an AUC. Quadrangles with any reported acreage were classified as presence, and all others were classified as absence.

Morisette et al. (2006) reported the area of suitable habitat for tamarisk in each of the 48 continental states and the District of Columbia. We recalculated that data for only those western states included in this analysis and also calculated new values from the model results of this study. As previously described, we trained the model by limiting the extent to locations where we had field data. When this model was projected onto the entire United States, almost all of the eastern United States had very high clamping values (data not shown). Thus, we limited our analyses to the western United States. This analysis was conducted by examining the continuum from unsuitable to suitable habitat and selected areas in the 99th quantile and the 90th quantile of suitability (referred to as high and moderate suitability, respectively) and totaling the number of $1-\mathrm{km}^{2}$ pixels in each of these categories by state.

\section{RESUlTS}

The Maxent models and validation tests showed strong performances in predicting suitable habitat for tamarisk. The average AUC value calculated by Maxent for the 25 model iterations was 0.930 for the training data and 0.926 for the test data. The distance-to-water variable had the most predictive contribution in all models, averaging $58.1 \%$ (Table 1). Habitat suitability increased with decreasing distance to water. Mean temperature of the warmest quarter averaged $18.4 \%$, and precipitation of the wettest month averaged $3.8 \%$ of the predictive contribution to model results. The relationship with the warmest quarter is a logistic curve where suitability is low at cooler temperatures, increases quickly at intermediate temperatures, and is greatest at high temperatures. Habitat suitability was greatest, with relatively lower precipitation values in the wettest months. All other variables contributed $<3 \%$ to the model.

Independent validation tests, using presence data $(30 \%$ of presence points combined with quarter quadrangles data set) and absence data (from our 2006 study) also demonstrated strong model performances. The AUC using all presence locations and absence data from the 2006 data set was 0.965 . Other metrics included sensitivity (0.938), specificity (0.936), correct classification rate (0.937), and kappa (0.872). Using the quarter quadrangle data, metrics included an AUC of 0.735 , sensitivity of 0.780 , specificity of 0.690 , correct classification rate of 0.700 , and kappa value of 0.635 . These values are lower, but the sensitivity value, which was 
a)

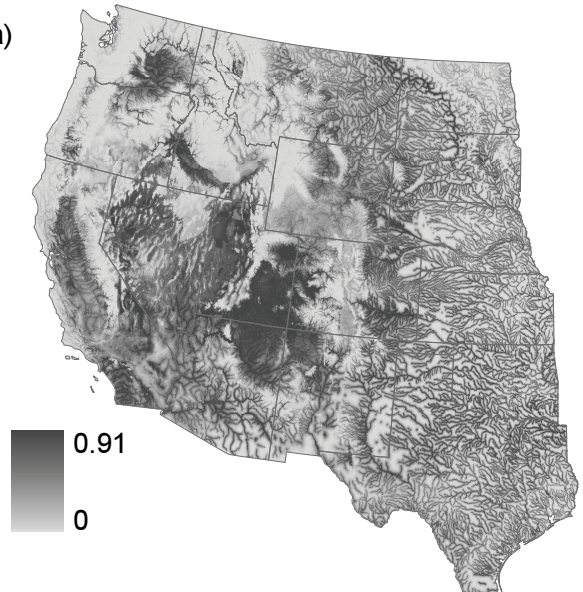

b)

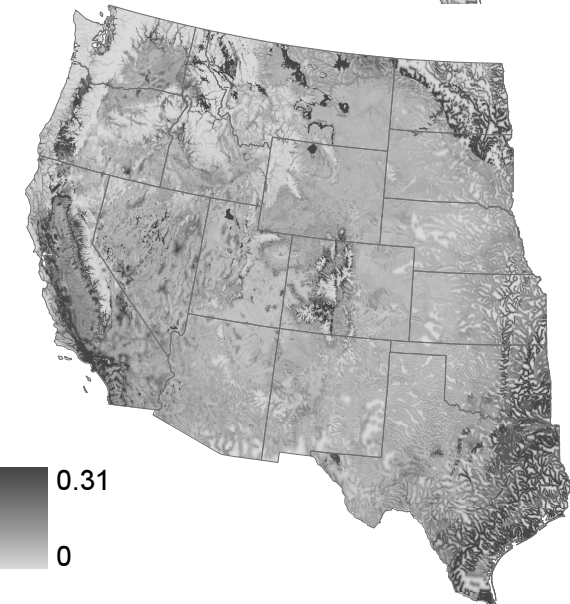

c)

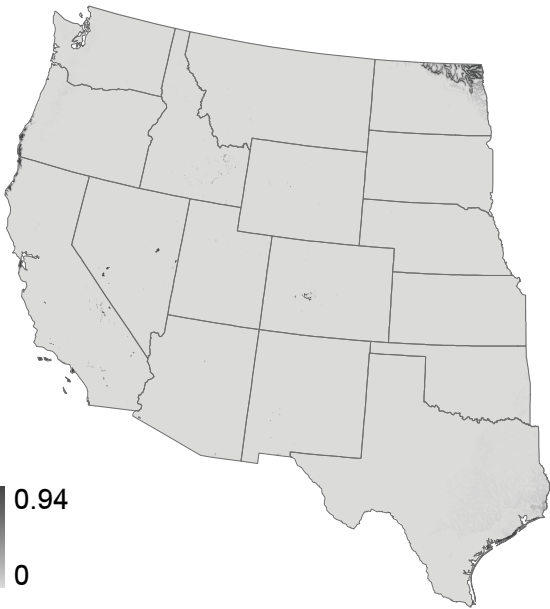

Fig 2. Maxent model results across 25 model iterations withholding a different random $30 \%$ of the data in each test run: (a) average habitat suitability, (b) standard deviation among the model iterations, and (c) average clamping (degree of departure from the environment captured by the training locations). Projection: USA Albers Equal Area Conic.

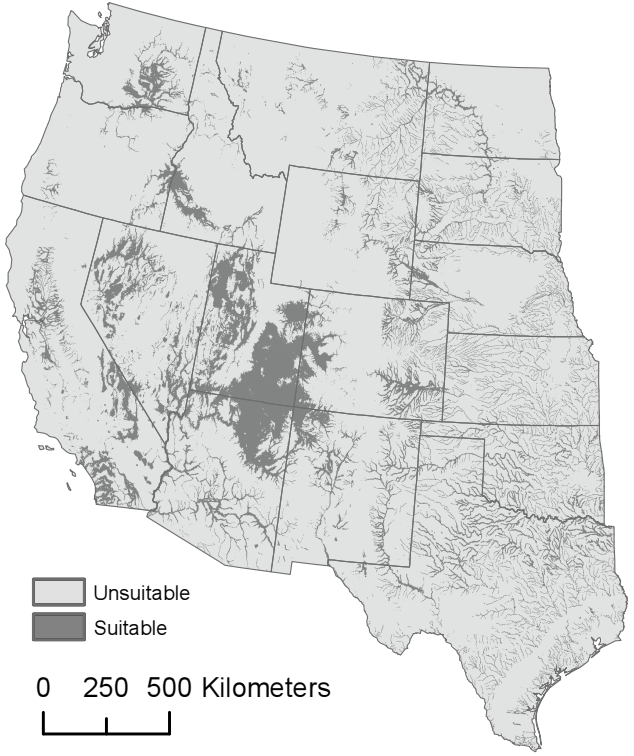

Fig 3. Binary map of suitable and unsuitable habitat for tamarisk using the 10 percentile training presence threshold (0.52). Projection: USA Albers Equal Area Conic.

still relatively good, should be given more weight due to the nature of the quarter quadrangle data set. We can be relatively certain that quarter quadrangles with reported acreage are accurate as far as presence is concerned, but we cannot say the same for absence locations, as it would be difficult to search every quarter quadrangle exhaustively for a single tamarisk seedling or plant.

Suitable habitat noticeably aligns with water bodies (Fig. 2a), as expected by the high contribution of the distance-to-water variable. Distinct patches occur in the southwestern United States, particularly Utah and Arizona. A high standard deviation among model runs notably occurs along the Pacific crest, spots of Montana and Idaho, and along the eastern edge of our study area (Fig. 2b). Minimal clamping occurred (Fig. 2c) and was in locations primarily distinct from the areas with high suitable habitat, suggesting that predictions are not lowered by uncertainty related to instability (i.e., high standard deviation) or extrapolation to novel environments (i.e., clamping). Classifying our suitability map into the binary categories of suitable and unsuitable habitat highlights associations between tamarisk and the water bodies noted with Figure $2 \mathrm{a}$ (Fig. 3). 


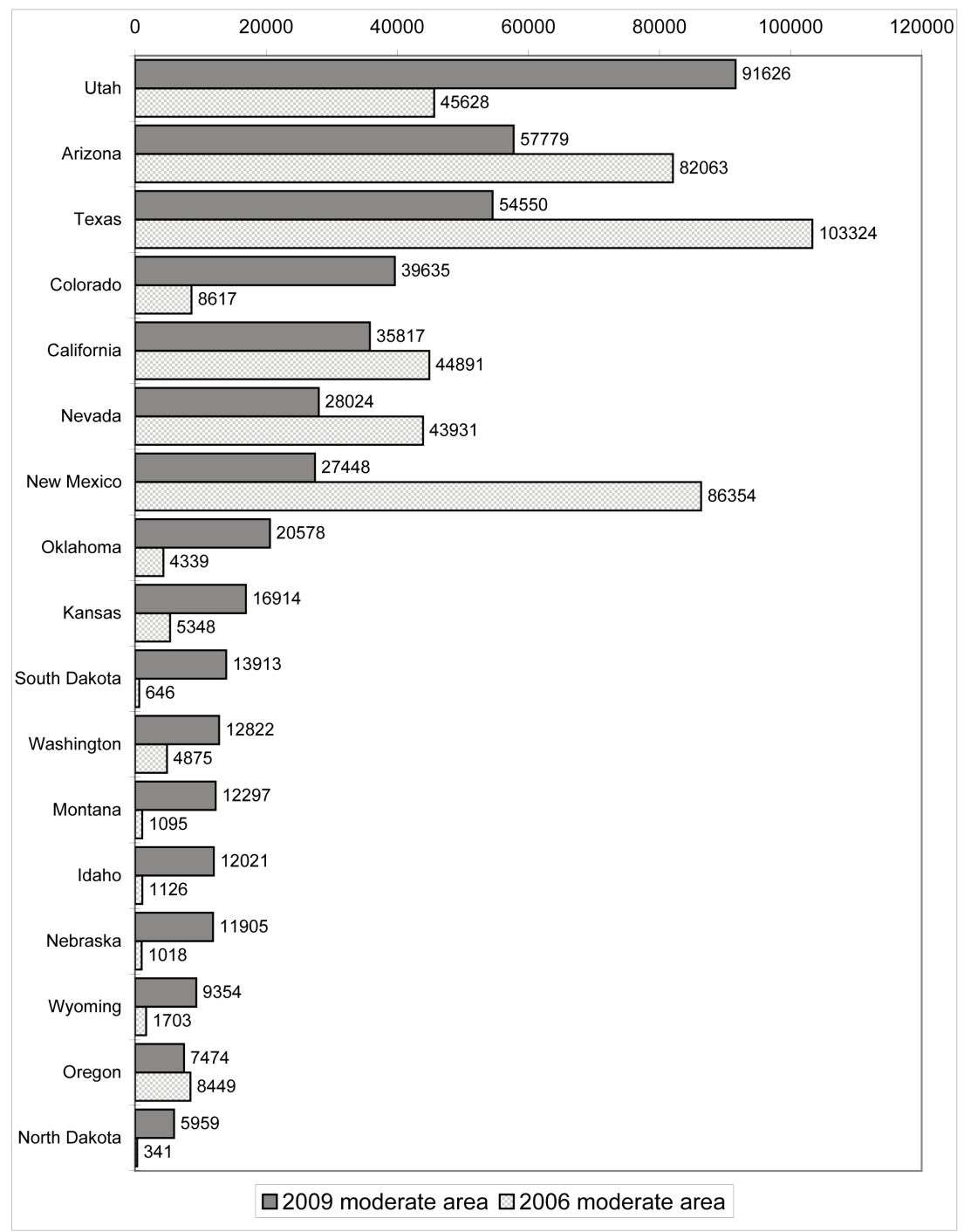

Fig 4a. Predicted area $\left(\mathrm{km}^{2}\right)$ of suitable habitat by state for our current model and for the Morisette et al. (2006) model for moderate habitat suitability.

Utah ranked highest by area and by percent of area both for moderately and highly suitable habitats (Fig. 4, Appendix). Arizona and Colorado exchanged the second and the third rankings among the 4 categories. Kansas ranked last for highly suitable habitat, and North Dakota and Oregon were ranked the least moderately suitable habitat by area and percent of area, respectively. Overall, patterns of our model results were similar to the distribution of field data and patterns exhibited in Figures 2 and 3. These results differ from the 2006 model, where California, Washington, Texas, and Arizona each ranked highest in one of the 4 categories.

\section{Discussion}

Existing models for tamarisk distributions in the United States are few and are generally constructed at small scales for local management of infestations. Evangelista et al. (2008) modeled tamarisk distribution for the Grand Staircase-Escalante National Monument in 


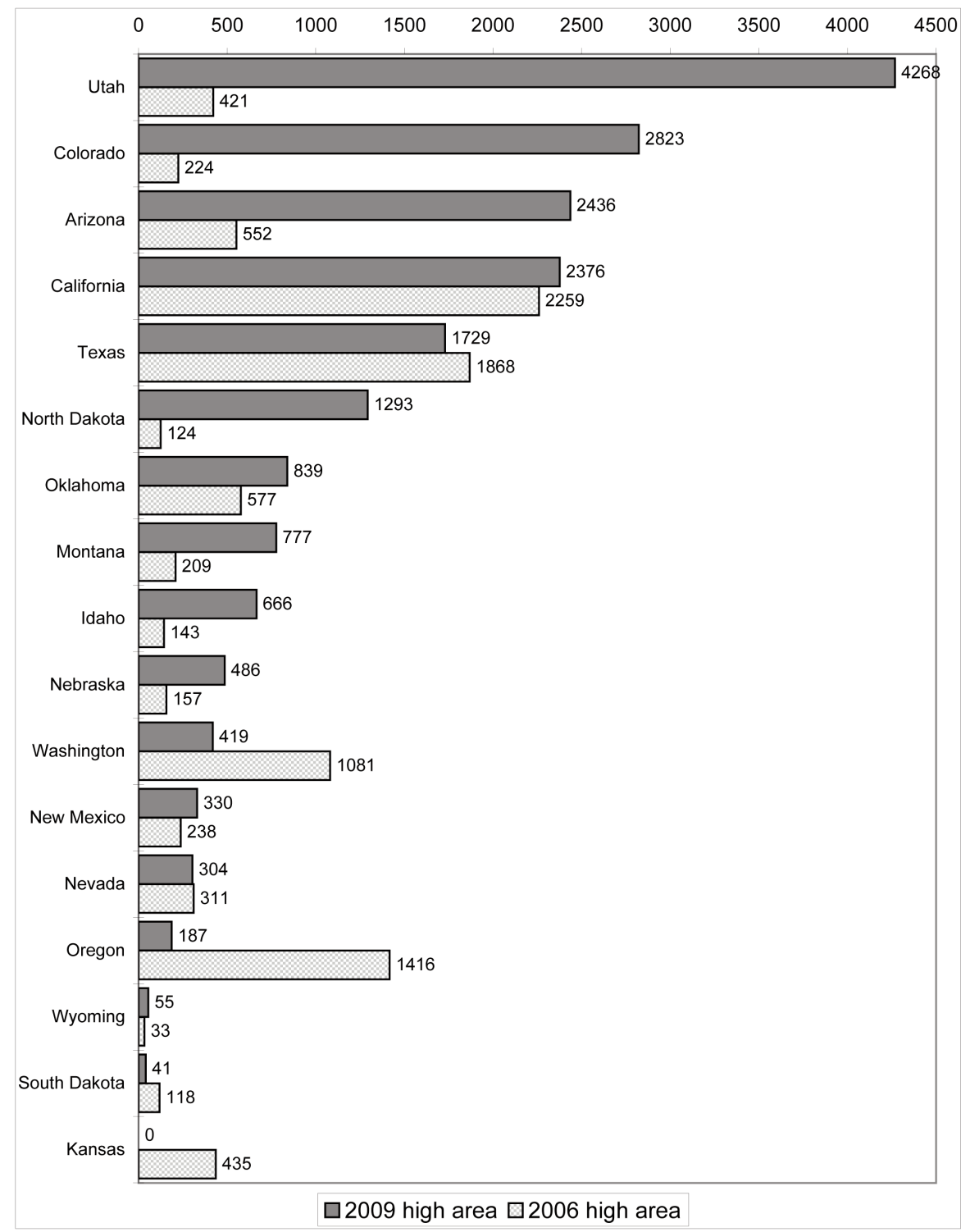

Fig 4b. Predicted area $\left(\mathrm{km}^{2}\right)$ of suitable habitat by state for our current model and for the Morisette et al. (2006) model for high habitat suitability.

Utah, primarily using a suite of topographic variables to test multiple modeling techniques. Most of the models they tested could reasonably predict where tamarisk would occur, with overland distance-to-water being the most important predictor. While the spatial extent of their study area was much smaller (i.e., approximately 2 million acres), their study corroborates the importance of water as a predictor of suitable tamarisk habitat at all scales.
Kerns et al. (2009) modeled tamarisk in the northwestern United States, but at this scale, distance-to-water was only marginally important and was outweighed by climatic factors. Maximum temperature was the most important factor, and was correlated with our second most important factor, mean temperature of the warmest quarter. Friedman et al. (2005) found a strong relationship between mean annual minimum temperature and tamarisk presence in the western United States. They did not 
examine the relationship between tamarisk presence and mean annual maximum temperature, but maximum temperature of the warmest month and minimum temperature of the coldest month were highly correlated $(r=$ $0.79)$.

Morisette et al. (2006) used remote sensing data and presence-absence data to create a National Tamarisk Map for the United States. Similar to our results, their study found that the southwestern states had the highest concentration of suitable habitat; however, our new model shows tamarisk having a much greater potential distribution across the entire western United States. We should note that despite the lack of data for the northwestern states, the 2006 model was able to predict occurrences in some areas. However, the new model adds new areas to the potential habitat and captures more of the currently known distribution than the 2006 model did. Additional agreement for southwestern states having the most tamarisk arises from a higher percentage of sampled stream reaches in Arizona (59\%) than in northern states $(<5 \%)$ (Ringold et al. 2008). Some differences in the 2 models can be attributed to different methodologies. The 2006 paper was focused on utilizing remote-sensing data and did not include distance-to-water as a predictor variable. Our model was driven by this variable. The models were also run for different spatial extents. The 2006 model included locations in the eastern United States, where tamarisk is not considered invasive, but the updated model focused on regions of known invasion. These differences, along with the additional data points, contributed to the differences between the models. As this paper was not meant to be a model comparison paper but rather an update to the current knowledge on the distribution of tamarisk, we have left an in-depth comparison between the 2 studies for future work.

\section{Caveats}

There are several caveats associated with our modeling that need recognition. First, the field data used to fit our models were compiled from disparate data sets of different collection designs and methods, including opportunistic sampling. As a result, the data are expected to be biased to varying degrees. Like other species distribution modeling techniques, Maxent is sensitive to these biases (Phillips et al. 2009), and they likely influenced our model results. We believe that at least some of these problems were alleviated by limiting the area from which background points could be drawn to the areas with field data samples (i.e., counties), but further investigation of the effects are warranted. Field data used for training and testing were not independent (i.e., they were drawn from the same data set) but were likely spatially autocorrelated (i.e., the data covaried geographically), which has been demonstrated to inflate AUC values (Segurado et al. 2006). Lastly, we suspect that the coarse resolution of the points extracted from quarter quadrangle data sets may cause inflated evaluation metrics due to this mismatch in resolution of the predictor variables $\left(1-\mathrm{km}^{2}\right.$ cells). Finer-resolution occurrence data paired with finer-resolution predictor variables would improve the model.

Maxent is a correlative model. We can use the variable importance measure to develop hypotheses about what we think may be driving tamarisk distribution, but we cannot determine causality with these methods.

This model describes potential suitable habitat for Tamarisk. However, moving toward a model of abundance would be more useful. Evangelista et al. (2007) created a model for tamarisk biomass based on estimates of height and cover in southwestern Colorado, but this has not yet been extended to a greater geographical area. Creating a model of presence locations of tamarisk can be somewhat misleading in that all areas of suitable habitat may not be locations where the tamarisk has a high impact. Obtaining these types of information across large spatial extents may be difficult, as the data are generally not available; however, the information would help managers prioritize locations for management activities. Additionally, this model was developed for the genus Tamarix rather than individual species or hybrids, because most available location data is not accurate to the species level. Creating species-specific models may lend greater insight into the factors associated with tamarisk invasion.

Neither the 2006 model nor the current model completely captured the full extent of tamarisk invasion in the United States. Models are hypotheses that can be useful for guiding management activities, but they can never perfectly represent truth. However, we believe the current model provides a more accurate 
representation of tamarisk extent because it incorporates improved distribution data, a different suite of predictor variables, and a different modeling technique.

\section{Conclusions}

The differences between the 2006 model of tamarisk habitat suitability and our current model clearly highlight the utility of iterative modeling for mapping invasive species distributions, as suggested by Stohlgren and Schnase (2006). Revisiting distribution models of invasive species is of particular importance to resource managers who require updated, accurate information to address management concerns and formulate strategic planning. With this example, the initial map (Morisette et al. 2006) informed the wider community of such modeling efforts and led others to contribute new occurrence information to our database. Furthermore, in the time between this study and the 2006 study, there have been advancements in modeling algorithms; and newly available predictor layers, updated occurrence data, and improved modeling expertise have become available. We expect these trends to continue. We believe most habitat suitability maps could be improved by these advances, which have strengthened our ability to predict suitable habitat for tamarisk and forecast new invasions. Finally, like the 2006 tamarisk model, our new model for the western United States can also guide future data collection efforts (to areas with high uncertainty or to high probability areas not yet searched), serve as an early warning of tamarisk's potential spread into new areas, and provide an estimate of current tamarisk infestation and its impacts to ecosystem processes.

\section{ACKNOWLEDGMENTS}

We thank entities and persons with tamarisk data sets who were willing to share their data for this work (Appendix). We thank Amy Randell, Sunil Kumar, and Alycia Crall for reviewing the manuscript. Logistic support was provided by the USGS Fort Collins Science Center and the Natural Resource Ecology Laboratory at Colorado State University. Any use of trade, product, or firm names is for descriptive purposes only and does not imply endorsement by the United States government.

\section{Literature Cited}

BAUM, B.R. 1967. Introduced and naturalized tamarisks in the United States and Canada [Tamaricaceae]. Baileya 15:19-25.

BAY, R.F., AND A.A. SHER. 2008. Success of active revegetation after Tamarix removal in riparian ecosystems of the southwestern United States: a quantitative assessment of past restoration projects. Restoration Ecology 16:113-128.

Brotons, L., W. Thuiller, M.B. Araujo, and A.H. Hirzel. 2004. Presence-absence versus presence-only modelling methods for predicting bird habitat suitability. Ecography 27:437-448.

CARLETON, M.A. 1914. Adaptation of the tamarisk for dry lands. Science 39:692-694.

Christensen, E.M. 1962. The rate of naturalization of Tamarix in Utah. American Midland Naturalist 68:51-57.

Colorado Department of Transportation. 2002. Colorado Department of Transportation Geographic Data. Colorado Department of Transportation.

DAVERN, T. 2006. A predictive model: tamarisk habitat in California and Colorado. Master's thesis, Colorado State University, Fort Collins, CO.

DiTomaso, J.M. 1998. Impact, biology, and ecology of saltcedar (Tamarisk spp.) in the southwestern United States. Weed Technology 12:326-336.

Elith, J., C.H. Graham, R.P. Anderson, M. Dudik, S. Ferrier, A. Guisan, R.J. Hijmans, F. Huettmann, J.R. Leathwick, A. Lehmann, Et AL. 2006. Novel methods improve prediction of species' distributions from occurrence data. Ecography 29:129-151.

[ESRI] Environmental Systems Research Institute. 2006. ArcMap 9.2. ESRI, Redlands, CA.

Evangelista, P., S. Kumar, T.J. Stohlgren, A.W. Crall, AND G.J. NEWMAN. 2007. Modeling aboveground biomass of Tamarix ramosissima in the Arkansas River basin of southeastern Colorado, USA. Western North American Naturalist 67:503-509.

Evangelista, P., S. Kumar, T.J. Stohlgren, C.S. JarneVich, A.W. Crall, J.B. Norman III, and D. BarNETT. 2008. Modelling invasion for a habitat generalist and a specialist plant species. Diversity and Distributions 14:808-817.

Evangelista, P.H., T.J. Stohlgren, J.T. Morisette, and S. KUMAR. 2009. Mapping invasive tamarisk (Tamarix): a comparison of single-scene and time-series analyses of remotely sensed data. Remote Sensing of Environment 1:519-533.

EveritT, B.L. 1980. Ecology of saltcedar-a plea for research. Environmental Geology (Berlin) 3:77-84. 1998. Chronology of the spread of tamarisk in the central Rio Grande. Wetlands 18:658-668.

Fielding, A.H., AND J.F. BELL. 1997. A review of methods for the assessment of prediction errors in conservation presence/absence models. Environmental Conservation 24:38-49.

Friedman, J.M., G.T. Auble, P.B. Shafroth, M.L. Scott, M.F. Merigliano, M.D. Preehling, and E.K. GrifFIN. 2005. Dominance of non-native riparian trees in western USA. Biological Invasions 7:747-751.

Gaskin, J.F., AND B.A. SchaAl. 2002. Hybrid Tamarix widespread in U.S. invasion and undetected in native Asian range. Proceedings of the National Academy of Sciences of the United States of America 99: $11256-11259$ 
Gaskin, J.F., AND P.B. Shafroth. 2005. Hybridization of Tamarix ramosissima and $T$. chinensis (saltcedars) with T. aphylla (athel) (Tamaricaceae) in the southwestern USA determined from DNA sequence data. Madrono 52:1-10.

Graham, J., G. Newman, C. Jarnevich, R. Shory, and T.J. Stohlgren. 2007. A global organism detection and monitoring system for non-native species. Ecological Informatics 2:177-183.

HaRRIS, D.R. 1966. Recent plant invasions in the arid and semi-arid southwest of the United States. Annals of the Association of American Geographers 56:408-422.

Hijmans, R.J. 2006. MkBCvars.AML. Version 2.3. Available from: http://worldclim.org/bioclim.htm

Hirzel, A.H., V. Helfer, and F. Metral. 2001. Assessing habitat-suitability models with a virtual species. Ecological Modelling 145:111-121.

Kerns, B.K., B.J. Naylor, M. Buonopane, C.G. Parks, AND B. RoGERs. 2009. Modeling tamarisk (Tamarix spp.) habitat and climate change effects in the northwestern United States. Invasive Plant Science and Management 2:200-215.

Kumar, S., S.A. Spaulding, T.J. Stohlgren, K. Hermann, T. SCHMidT, AND L. BAHLS. 2009. Potential habitat distribution for the freshwater diatom Didymosphenia geminate in the continental US. Frontiers in Ecology and the Environment 7:415-420.

LesicA, P., AND S. Miles. 2001. Tamarisk growth at the northern margin of its naturalized range in Montana, USA. Wetlands 21:240-246.

Lindgren, C., C. Pearce, and K. Allison. 2010. The biology of invasive alien plants in Canada. 11. Tamarix ramosissima Ledeb., T. chinensis Lour. and hybrids. Canadian Journal of Plant Science 90:111-124.

Morisette, J.T., C.S. Jarnevich, A. Ullah, W.J. Cai, J.A. Pedelty, J.E. Gentle, T.J. Stohlgren, and J.L. SCHNASE. 2006. A tamarisk habitat suitability map for the continental United States. Frontiers in Ecology and the Environment 4:11-17.

Natale, E.S., J. Gaskin, S.M. Zalba, M. Ceballos, and H.E. Reinoso. 2008. Tamarix species (Tamaricaceae) invading natural and seminatural habitats in Argentina. Boletin de la Sociedad Argentina de Botanica 43:137-145

National Invasive Species Council. 2008. 2008-2012 National Invasive Species Management Plan.

National Park Service. 2003. Natural Resource Information Portal [online]. National Park Service. Available from: https://nrinfo.nps.gov/reference.mvc/reference/.

PEarce, C.M., AND D.G. SMITH. 2007. Invasive saltcedar (Tamarix): its spread from the American Southwest to the northern Great Plains. Physical Geography 28:507-530.

Phillips, S.J., R.P. Anderson, And R.E. Schapire. 2006 Maximum entropy modeling of species geographic distributions. Ecological Modelling 190:231-259.
Phillips, S.J., M. Dudik, J. Elith, C.H. Graham, A. Lehmann, J. Leathwick, and S. Ferrier. 2009. Sample selection bias and presence-only distribution models: implications for background and pseudoabsence data. Ecological Applications 19:181-197.

Ringold, P.L., T.K. Magee, and D.V. Peck. 2008. Twelve invasive plant taxa in US western riparian ecosystems. Journal of the North American Benthological Society 27:949-966.

Robinson, T. 1965. Introduction, spread and areal extent of saltcedar (Tamarix) in the western United States. U.S. Geological Survey Professional Paper 491-A.

Scott, M.L., P.L. Nagler, E.P. Glenn, C. Valdes-CasilLas, J.A. Erker, E.W. Reynolds, P.B. Shafroth, E. Gomez-Limon, AND C.L. JonEs. 2009. Assessing the extent and diversity of riparian ecosystems in Sonora, Mexico. Biodiversity and Conservation 18:247-269.

Segurado, P., M.B. Araujo, and W.E. Kunin. 2006. Consequences of spatial autocorrelation for niche-based models. Journal of Applied Ecology 43:433-444.

Sexton, J.P., A. Sala, AND K. Murray. 2006. Occurrence, persistence, and expansion of saltcedar (Tamarix spp.) populations in the Great Plains of Montana. Western North American Naturalist 66:1-11.

Stockwell, D.R.B., And D. Peters. 1999. The GARP modeling system: problems and solutions to automated spatial prediction. International Journal of Geographic Information Science 13:142-158.

Stohlgren, T.J., And J.L. SChnAse. 2006. Risk analysis for biological hazards: what we need to know about invasive species. Risk Analysis 26:163-173.

Thomas, K., and P GuerTin. 2007. Southwest Non-native Invasive Plant Database (SWEMP07). U.S. Geological Survey, Southwest Biological Science Center (USGS-SBSC).

Thornton, P., S. Running, And M. White. 1997. Generating surfaces of daily meteorology variables over large regions of complex terrain. Journal of Hydrology 190:214-251.

Uowolo, A., D. Binkley, And E.C. Adair. 2005. Plant diversity in riparian forests in northwest Colorado: effects of time and river regulation. Forest Ecology and Management 218:107-114.

USDA NRCS. 2009. The PLANTS Database. National Plant Data Center, Baton Rouge, LA [cited 27 April 2009]. Available from: http://plants.usda.gov

Whitcraft, C.R., D.M. Talley, J.A. Crooks, J. Boland, AND J. GASKIN. 2007. Invasion of tamarisk (Tamarix spp.) in a southern California salt marsh. Biological Invasions 9:875-879.

Received 14 July 2010 Accepted 2 March 2011

See Appendix on page 175. 
APPENDIX. Data sets gathered that include data for tamarisk. Data were downloaded from www.niiss.org on 2 July 2008.

\begin{tabular}{lcc}
\hline Name & Sample size & NIISS.org \\
\hline Bay and Sher (2008) & 79 points & No \\
Bradshaw (Unpublished data 2006) & 2931 points & Yes \\
Colorado Department of Transportation (2002) & 48 polygons & Yes \\
Colorado project (www.niiss.org) & 53 points & Yes \\
Colorado State Parks mapping data $\quad 18$ points & Yes \\
$\quad$ Unpublished data 2003) & 5 polygons & \\
Davern (2006) & 639 points & Yes \\
Fingerprinting biodiversity (CSU and USGS field data; www.niiss.org) & 135 points & Yes \\
Sexton et al. (2006) & 20 points & No \\
Grand Staircase Escalante National Monument (Evangelista et al. 2008) & 1881 points & Yes/No \\
Hubbard Lake (www.niiss.org) & 10 polygons & Yes \\
Uowolo et al. (2005) & 11 points & No \\
National Park Service (2003) GIS data & 1291 points & Yes/No \\
National Wildlife Refuge Project (Unpublished data) & 2 polygons & Yes \\
Sengupta et al. Nevada mapping data (Unpublished data 2005) & 154 points & Yes \\
NIISS Citizen Science Website Projects (www.citsci.org) & 100 points & Yes \\
North Dakota Department of Agriculture (Unpublished data 2003) & 2648 points & Yes \\
Otero County, Colorado (Unpublished data, 2003) & 1422 points & No \\
Robinson (1965) & 143 points & Yes \\
U.S. Bureau of Land Management, Royal Gorge weed data & 19 points & No \\
$\quad$ Unpublished data 2003) & & \\
South Dakota Department of Agriculture (Unpublished data 2006) & 16 polygons & Yes \\
Southwest Exotic Plant Mapping Program (Thomas and Guertin 2007) & 899 points & Yes \\
Tamarisk Coalition (Unpublished data 2008) & 2267 polygons & Yes \\
Colorado Natural Heritage Program (Unpublished data 2008) & 11 points & No \\
U.S. Bureau of Land Management, Utah office noxious weed data & 247 points & No \\
Kernpublished data 2006) & & \\
Kerns et al. (2009) & 1044 points & No
\end{tabular}

